\title{
The Idea of Religious Moderation from Arabian Classical Literature: Ibn Tufayl's (1110-1185 CE) Hayy ibn Yaqzan
}

\author{
Titis Thoriquttyas $^{1}$, Meidi Saputra ${ }^{2}$, Yusuf Hanafi ${ }^{3}$, Immamul Huda ${ }^{4}$ \\ \{titisthoriq.fs@um.ac.id ${ }^{1}$, meidi.saputra@gmail.com², yusufhanafi@gmail.com ${ }^{3}$, \\ immmanul.huda@gmail.com $\left.{ }^{4}\right\}$ \\ ${ }^{1234}$ Universitas Negeri Malang, Jawa Timur, Indonesia
}

\begin{abstract}
This study aims to examine the epistemology 's narratives of the idea of religious moderation (wasatiyah) in arabian classsical literature. Written as a philosophical work, Ibn Tufayl's (1110-1185 CE) Hayy ibn Yaqzan incorporates in its story many elements that could be regarded as elements of the civilization, the mysticism on Islamic epistemology. In this paper we will analyze these elements of the wasatiyah and try to reassemble them into a clear theory to arrange the building of religious moderation idea. This study uses a qualitative descriptive approach, and categorizes into library research. Literary data collection techniques through the editing process (preparation of frameworks and procedures for implementation of the concept), organizing the data (coding sheet), data discovery, data analysis (content analysis) and interpretation (phenomenology). Conclusion of this study is point out the bridging effort and legacy from Ibnu Tufayl on the notions of moderation. Through this idea, we propose mechanisms to explain the legacy from Ibn Tufayl to re-confront the 'moderation', it is the uniqueness and originality for Islamic basis of epistemology.
\end{abstract}

Keywords - Hayy ibn yaqzan; ibn tufayl; religious moderation

\section{Introduction}

Ibn Tufayl is a Muslim philosopher who has long been a study of Islamic and western academics [1], [2]. Ibn Tufayl's notion of moderation is still not widely reviewed, because most of the previous research focusing on the study of his thoughts is still oriented towards the scope of mysticism the study of the Qur'an and his contribution to the world west [3]-[5]. Therefore, this research seeks to offer a re- reading of the book of Hayy Ibn Yaqzhan, one of Ibn Tufayl's masterpiece full of philosophical values by linking it to the study of Islamic moderation.

As one of the Muslim philosophers who came from the periodization of the mid-Islamic era, Ibn Tufayl has contributed in several scientific fields, one of which is Islamic Philosophy [1], [3], [6]. A classical literary work from the Middle Ages, entitled Hayy bin Yaqzan, is one of the representations of the triumph of science, literature and Islamic civilization [5], [7]. This 
classical literature can be categorized in the form of allegorical-philosophical novels, because the contents contained therein are imaginative allusions of the author. The novel tells the life struggle of a human child, named Hayy. Hayy is the core character in the novel and he is said to have been raised and cared for by a forest deer isolated from the human world. However, the uniqueness of this novel is the story of Hayy in old age who lives a life full of knowledge, wisdom and truth. Researchers are interested in photographing the dimensions of moderatism which is reflected in the story of Hayy, while the term moderatism in this study focuses on the position of an individual who lives in an "in-between" frame. It is this "in between" frame that positions Hayy to reach a capable level of knowledge even though he was born and developed without going through an explicit learning process.

Ibn Tufayl, whose full name is Abu Bakar Muhammad Ibn Abd al-Malik Ibn Muhammad Tufayl, was one of the leading Muslim philosophers of the muwahiddun dynasty in Granada, Spain [1], [6], [7]. One of his masterpieces is Hayy Ibn Yaqzhan's treatise which is often written with a more complete title as Asrar al Falsafah al Isyraqiyyah. The novel, written in the 12th century, has been translated into several foreign languages, namely Latin "Philosophus Autodidactus" by Pockokcke in 1671, Spanish in 1910, French in 1952 [1], [2], [5], [7].

The treatise of Hayy ibn Yaqzan is also believed by some linguists and literary experts to have a contribution and influence on the development of European literature. One proof is the literary work entitled, el Criticon by Baltazer and the story of Robinson Crusoe entitled The Life and Strange Surprising Adventure of Robinson Crusoe by De Foe in 1719 [3].

Study that examines the thoughts of Ibn Tufayl are actually quite a lot. Starting from the dimensions of economic [5], educational [7], political and and governance systems [8], social [4] and grammatical [9], Ibn Tufayl's thought proved that it was compatible with contextual studies. However, as far as the scientific search of previous studies, the researcher found that there was an academic gap that had not yet comprehensively discussed about the thought of religious moderation of Ibn Tufayl. This study offers a comprehensive academic horizon on the moderation of Ibn tufayl in Hayy ibn Yaqzhan's novel.

This research aims to uncover a unique perspective in viewing the study of moderatism with sources of medieval literary works that are loaded with philosophical and religious thought content. Through this review, it emphasizes the richness of the treasures of thought and complex literary dynamics that present a variety of interesting interpretations.

\section{Methods}

This study uses a qualitative descriptive approach, and the type of research used is library research. Literary data collection techniques through the editing process (preparation of frameworks and procedures for implementation of the concept), organizing the data (coding sheet), data discovery, data analysis (content analysis) and interpretation (phenomenology). The stages of content analysis in this study involves several steps (determine the main issues in Hayy ibn Yaqzhan's novel; arrange a framework of thought in moderation; determine data collection methods by making coding sheets; determine the method of data analysis and interpretation of data. Researchers used reference literature that discussed the thoughts of Ibn Tufayl about the various scientific disciplines. The use of literature that emphasizes on novelty of the study is the point of strength of this study 


\section{Result and Discussion}

Hayy is a fictional character introduced by Ibn Tufayl [3], [5]. In short, the story of Hayy begins with a narrative about his birth and the process of beginning. In line with Hayy's healthy physical growth, his mind and mind are increasingly developing. He noticed and began to think about everything that was around him. He found a way to make ends meet. His feelings and thoughts encourage him to take the decision that his genitals need to be closed. More than that he is able to use his mind in such a way that it can understand the nature of empirical nature and is able to think things that are metaphysical. His deep thinking about everything captured by the five senses gives rise to the belief in the existence of God, the creator of the universe. The belief in the existence of God as the ultimate truth, pushed Hayy to try to relate and be close to Him. Through philosophical thought, he knows the nature of nature. He also obtained true ma'rifah (knowledge) and true happiness. To achieve this goal, he trained himself by fasting for 40 days in a cave [1], [3]. With great sincerity, he tried to free himself from the empirical world through full contemplations to God. Finally, he got what he wanted, namely ittihad (merging with Allah) or ittishal (directly related) with God constantly [6], [7]. Tufayl sought to dramatically develop the development of human theoretical reasoning from the perception of a feeling that is still rough into a beautiful vision of God.

When he was in such esoteric situations and experiences, he met a man, whose name was Absal. Absal came from an island is close from where Hayy lived. Absal thought that the island where Hayy was, was not inhabited by humans and he thought it was suitable to alienate himself from the community. On this island he tried to foster piety and faith. Hayy does not understand human language. After being absent from teaching him, the two communicated fluently, told each other's experiences, and exchanged ideas. Absal told Hayy about the Qur'ani concepts, which pertain to God, angels, prophets and others [2], [10], [11].

Through information obtained from Absal, Hayy realized that the philosophical method he possessed had brought him to the level of knowledge that was in line with the teachings of Absal's religion. He also knew that the person who carried the statement with the right words was an apostle and he believed in him and acknowledged his apostleship. In contrast, Hayy also explained his experience with God to Absal. Hayy's testimony reinforces Absal's beliefs about the teachings of the religion he received and that reason and revelation (al-manqul wa al$\left.m a^{\prime} q u l\right)$ on Hayy's invitation were intended to inform the intrinsic ma'rifah he obtained to the inhabitants of the island. The island was ruled by a king named Salman, Absal's best friend. Salman accepted religious teachings as conveyed by the prophet, in other words Salman was more interested in the meaning of texts (exoteric)(Ismail, Rofiqoh, Sari). He likes to live in the midst of society and forbid others to live in solitude, uzlah. After absurdly expressing the essential ma'rifat knowledge experienced by Hayy, the inhabitants of the island received Hayy enthusiastically (Masudi, Sari). However, after Hayy explained his philosophical knowledge and thought, it turned out that the population was mocking him. Hayy learned from his experience that ordinary people do not understand and are unable to accept true ma'rifat. Ma'rifat can only be understood by special people, who in religion have achieved higher dignity compared to ordinary people [4], [12]. People are not able to reach pure concepts. Hayy also realized that association brought damage to society and to repair it was very much needed religious teachings brought by the prophet [10], [13], [14]. Because the prophet knows the human soul in general. He apologized to Salman and his citizens, and admitted his own mistake in forcing them to search for hidden meanings in the holy Qur'an. The parting message is that they must adhere to the provisions of the Shari'a law which they have believed so far. They fill the rest of their lives by worshiping fully to God 


\section{Conclusion}

Philosophically, the work of Ibn Tufayl Hay ibn Yaqzan is a great explanation of the theory of knowledge, which seeks to align Aristotle with Neo-Platonists on the one hand, and AlGhazali with Ibn Bajjah on the other. Ibn Tufayl, following the middle road bridging the gap between the two parties. As a rationalist, he sided with Ibn Bajjah in fighting Al-Ghazali and turning Sufism into rationalism. As a Sufism expert, he sided with Al-Ghazali in fighting Ibn Bajjah and turned rationalism into Sufism. Through the philosophical romance of Hayy ibn Yaqzan, Ibn Tufayl emphasized that philosophy and religion do not conflict, in other words, reason does not conflict with revelation.

Ibn Tufayl put Hay as the personification of the natural spirit of man who was illuminated from "above". The spirit is in accordance with the spirit of the Prophet, whose remarks need to be interpreted metaphorically. Ibn Tufail realized, knew, and related to Allah through the thought of pure reason, which can only be done by special people (ahl mal-ma'rifat). Laymen cannot do it. Thus, for ordinary people it is necessary to have religious teachings brought by the Prophet. Religion is revealed to all people at all levels. Philosophy can only be reached by highminded people who are few in number. Religion is full of comparisons, similarities, and anthropomorphic perceptions, so that it is quite easily understood by many people. Philosophy is part of esoteric truth, which interprets these symbols in order to obtain essential insights.

In fact, Ibn Tufayl tried earnestly to reconcile philosophy and religion. Hay in his philosophical romance, he symbolized as a mind that can communicate with God. While Absal, he symbolizes as revelation (religion) in an esoteric form, which carries the essence (truth). While Salaman, he symbolizes revelation (religion) in the exoteric form, which also brings the truth. The truth produced by philosophy does not conflict (in line) with the truth desired by religion because the source is the same, namely God

\section{Funding}

This work was supported by PNBP Research Grant from Universitas Negeri Malang, 2019, No. 20.3.258/UN32.14.1/LT/2019

\section{Acknowledgement}

The authors would like to thank their colleague for their contribution and support to the research. They are also thankful to all the reviewers who gave their valuable inputs to the manuscript and helped in completing the paper.

\section{Conflict of Interest}

The authors have no conflict of interest to declare. 


\section{References}

[1] R. Brague, "Cosmological Mysticism: The Imitation of the Heavenly Bodies in Ibn Tufayl's Hayy ibn Yaqzan,” Grad. Fac. Philos. J., vol. 19, no. 2/1, pp. 91-102, 1997.

[2] Faturohman, "Ibnu Rusd Dan Pemikirannya," Tsarwah J. Ekon. dan Bisnis Islam, vol. 1, no. 1, pp. 109-122, 2017.

[3] D. Gutas, "Ibn Ṭufayl on Ibn Sīnā’s Eastern Philosophy," Oriens, pp. 222-241, 1994.

[4] S. S. Hawi, "Ibn Țufayl: On the Existence of God and His Attributes," J. Am. Orient. Soc., vol. 95, no. 1, pp. 58-67, 1975.

[5] L. Uswaroh, "At Thibaq Wa Al Muqabalah Fi Qishah Hayy Bin Yaqzan Li Ibnu Thufail: Ad Dirasah Al Balaghiyah," Uin Sunan Ampel Surabaya, 2015.

[6] G. Holzman, "The theory of the intellect and soul in the thought of Rabbi Moshe Narboni Based on his commentaries on the writings of Ibn Rushd, Ibn Tufayl, Ibn Bajja and al-Ghazali," Hebrew University of Jerusalem, 1996.

[7] F. Hidayah, "Mengkaji Teori Humanistik Dalam Novel Hayy Ibn Yaqdzhan Karya Ibnu Thufail," AL-WIJDÁN J. Islam. Educ. Stud., vol. 2, no. 1, pp. 17-28, 2017.

[8] Halimatuzzahro, "Filsafat Politik Ibnu Rusyd," Refleks. J. Filsafat Dan Pemikir. Islam, vol. 17, no. 1, pp. 19-93, 2017.

[9] Z. A. Siddiqi, "Philosophy of Ibn Tufayl (PhD Thesis). Aligarh Muslim University.," Department Of Philosophy \& Psychology Aligarh Muslim University, 1963.

[10] F. W. Sari, "Konsep Akal Dan Wahyu Menurut Ibnu Thufayl.," Jurusan Aqidah Filsafat Fakultas Ushuluddin, Adab Dan Dakwah Institut Agama Islam Negeri (Iain) Tulungagung, 2014.

[11] S. Siregar, "Filsafat Hayy Ibn Yaqzan: Dialektika Akal Dan Wahyu Menurut Ibn Thufail," Ushuluddin dan Studi Islam Universitas Islam Negeri Sumatera Utara., 2017.

[12] L. Marnisah, H. Aravik, and F. Zamzam, "Dari Kisah Hayy Bin Yaqzhan Sampai Moralitas Ekonomi; Pemikiran Ekonomi Ibn Thufail,” Salam J. Sos. Dan Budaya Syar-i, vol. 6, no. 4, pp. 343-354, 2019.

[13] F. Ismail, "Pengembangan Karakter melalui Pendidikan Agama Islam," J. Ilm. Iqra, vol. 7, no. 2, 2013.

[14] K. Rofiqoh, "Epistimologi Ibn Thufail Dalam Mencari Kebenaran," Jurusan Filsafat Agamafakultas Ushuluddin Adab Dan Dakwahinstitut Agama Islam Negeri (Iain) Tulungagung, 2015. 